\title{
Authorised Histories: Human Remains and the Economies of Credibility in the Science of Race
}

\author{
RICARDO ROQUE \\ Institute of Social Sciences, University of Lisbon
}

In this article, I approach the issues of missing data and testimony in the context of the history of race science, craniology, and collections of human remains housed in museums. In the context of comparative race science, human skulls were intended to be examined in association with short histories and biographical data about their pasts. I investigate how and why such documentation and historicising work formed part of a knowledge economy in the nineteenth century that, at the microscopic scale of the archival documents linked to the collections, was intended to verify the authority of human remains as testimonial evidence of distinct human races.

I then show that the association of documents, narratives and historical information with collections of human skulls was a common and important practice in the field of 'anthropology' (which, in nineteenth-century usage, was referred to as the 'science of race', or 'natural history of man', and later renamed 'physical anthropology'), and a significant part of its claims to scientificity. At the time, the notion of 'race', even in craniology (race science's most paradigmatic manifestation), was more than a construct derived purely from the observation of human remains. In the context of such collections, 'race' was an artefact entangled in a network of documents, archives, and narratives associated with anatomical collections - its coming into being shaped, and was shaped by, how collectors, race scientists, and museologists produced, curated, and authenticated the histories and records of specific human skulls over time.

I concentrate in this article on the relationship that the historiographic domain maintained with the production of credibility. That is, I focus on the authority of collectors' testimonies, and on how the authenticity of these testimonies was managed within the field of the race science that was craniology. ${ }^{1}$ Historical documentation, including narratives about the pasts and the identities of collections, served as technologies that attested to the credibility of using the testimony of human remains as evidence in support of racial theories, genealogies, and taxonomies.

In proposing this argument, I draw inspiration from the seminal studies by historians Steven Shapin and Simon Schaffer on the importance of 'economies of

An earlier version of this paper was presented as a keynote address to the workshop on 'Missing and Missed: The Subject, Politics and Memorialisation of South Africa's Colonial and Apartheid Dead', in 2018. A modified version appeared in French under the title 'A Little History Attached to Them: Authenticité et crédibilité du témoignage matériel dans les collections anthropologiques, 1850-1900', Revue d'Histoire des Sciences Humaines, 27, 2015, 143-164. I thank the journal's editors for permission to reuse and rework the article here. Thanks also to the anonymous reviewers of Kronos for their insightful comments. This version was translated from Portuguese by Martin Dale.

1 In previous work, I have noted the importance of this archiveological and historiographic domain in the epistemology of racial anthropology. For studies in which I explore these themes, see R. Roque, Headhunting and Colonialism: Anthropology and the Circulation of Human Skulls in the Portuguese Empire, 1870-1930 (Basingstoke: Palgrave Macmillan, 2010), especially Chapter 6; and R. Roque, 'Stories, Skulls, and Colonial Collections', Configurations, 19, 1, 2011, 1-23. 
credibility' to the origins of modern science in seventeenth-century England. ${ }^{2}$ Shapin and Schaffer argued that science based on the experimental production of facts in a laboratory is modelled on the legal production of de facto evidence in court. ${ }^{3}$ For this reason, the management of scientific evidence in (museum and other) laboratories required the mobilisation of social, literary, and material conventions to verify the trustworthiness and credibility of testimony provided by scientists, machines, instruments or material objects. Shapin, in particular, showed how the ethos and social status of 'the gentleman' played a fundamental role in processes of social accreditation linked to scientific reporting and laboratorial evidence. 'Science,' Shapin generalised, 'like finance, is a credit-economy: there are activities in which, if you subtract credibility, there is just no product left: neither a currency nor a body of scientific knowledge. ${ }^{5}$

This claim is equally valid for the area of race science, especially that based on the comparative study of human skulls. In particular, the anthropology of the mid nineteenth century (with its physical or biological tradition founded on comparative anatomy) involved management technologies that conferred credit and authority on certain kinds of biological material - and human skulls in particular - that were seen at the time as crucial evidence of the existence of 'race'. Thus, throughout the nineteenth and early twentieth centuries, the human skull held a privileged epistemological status as 'the paradigmatic object' for physical anthropologists. ${ }^{6}$ Skulls enjoyed a high level of trustworthiness as 'evidential objects' of human, and especially racial, diversity. ${ }^{7}$ By the mid nineteenth century, the institutionalisation of physical anthropology meant that museum spaces (for guarding and archiving collections) were combined with laboratory spaces (for the observation and technical manipulation of osteological materials par excellence).

In the laboratory spaces attached to anthropological museums, skulls were thought to be the most reliable concrete materials from which to make anatomical and anthropometric observations, and construct racial genealogies and taxonomies. The skull had an almost undisputed authority in the field of race science. However, in concrete terms, when compared with one another, not all skulls held equal degrees of

2 In particular, S. Shapin and S. Schaffer, Leviathan and the Air-Pump: Hobbes, Boyle, and the Experimental Life (Princeton, NJ: Princeton University Press, 1985). In the 1970s and 1980s, scientific credibility became one of the main themes in social studies of science. For a review of the issue of credibility (as opposed to validity) and its importance for science, see S. Shapin, 'Cordelia's Love: Credibility and the Social Studies of Science', Perspectives on Science, 3, 3, 1995, 255-275. It should be noted that these themes did not have an equivalent impact on the historiography of anthropology, especially physical anthropology.

3 Shapin, 'Cordelia's Love'. See also B. J. Shapiro, 'Testimony in Seventeenth-Century English Natural Philosophy: Legal Origins and Early Development', Studies in History and Philosophy of Science, 33, 2, 2002, 243-263.

4 S. Shapin, "A Scholar and a Gentleman": The Problematic Identity of the Scientific Practitioner in Early Modern England, History of Science, 24, 1991, 279-328; S. Shapin, A Social History of Truth: Civility and Science in Seventeenth-Century England (Chicago, IL: University of Chicago Press, 1994).

5 Shapin, 'Cordelia's Love', 258. See also the collection of Shapin's essays: S. Shapin, Never Pure: Historical Studies of Science as if it was Produced by People with Bodies, Situated in Time, Space, Culture, and Society, and Struggling for Credibility and Authority (Baltimore, MD: John Hopkins University Press, 2010). The problem of the credibility of science in relation to other forms of knowledge (religion, for example) was developed by Gieryn within the concept of boundary work; T. Gieryn, Cultural Boundaries of Science: Credibility on the Line (Chicago, IL: University of Chicago Press, 1999).

6 See A. Zimmerman, Anthropology and Antihumanism in Imperial Germany (Chicago, IL: University of Chicago Press, 2001). Just as he had previously enjoyed in phrenology. On the historical problem of the rise and fall of the credibility of phrenology as a science of the skull, see R. Cooter, The Cultural Meaning of Popular Science: Phrenology and the Organisation of Consent in Nineteenth Century Britain (Cambridge: Cambridge University Press, 1984). Gieryn, Cultural Boundaries of Science, ch. 3.

7 See M. Engelke, 'The Objects of Evidence', Journal of the Royal Anthropological Institute, 14, 2008, S1-S21. 
epistemological authority. That is, even at the height of racial craniology, the authority of particular skulls, when considered individually and specifically, was unevenly distributed. For this reason, those using skulls as evidence in race science faced the arduous task of ensuring their credibility. To a large extent, this involved producing and preserving archives comprised of short historical accounts associated with each 'specimen'. Not all skulls collected carried an equal degree of authority in terms of testifying to the differences between human races. In short, not all skulls participated in the special class of 'scientific objects', defined by Shapin as 'authorised objects':

The conditions of credibility of such things depend to such an extent on a certain form of economy [of credibility] that it is tempting to recognize a distinct class of what might be called 'authorized objects'. Not all scientific objects have that authorized character and those conditions of credibility. ${ }^{8}$

It is important, therefore, to examine how - via what practices and techniques, and under what conditions and circumstances - human skulls could acquire, or fail to acquire, credibility as 'authorised objects' in the field of racial anthropology.

In my view, the constitution of skulls as 'authorised objects' in the field of physical anthropology must be understood in light of the simultaneous constitution of what I propose to call, by analogy, 'authorised histories'. From the early nineteenth century until at least the beginning of the twentieth century, the work of collecting human skulls in the field of anthropology included accumulating histories and documents about the skulls. That the two processes were part of the same historical phenomenon is reflected in the archives and databases housed in museums and other institutions. In addition, the two processes shared an epistemology of race science within which the credibility of racial theories and classifications depended on the authenticity that could be conferred on the testimony of these objects by means of credible historical documents and accounts. In other words, understanding the primacy attributed to the materiality of the human skeleton in race science requires us to pay attention to documentary materials and historiographical practices that aimed to guarantee the authority of human bones as evidence for racial scientific theories. The historical accounts and documents attached to bones constituted one of the most important technologies used in the administration of the scientific credibility attributed to human skulls and, consequently, the authority of the theoretical propositions and conjectures that were deduced from them. Consequently, the credibility attributed to skulls as scientific objects, in the form of 'authenticity' for example, was closely linked to the credibility of the associated historical information. A study of catalogues, correspondence and archives linked to scientific collections of human skulls, created mainly from the 1850 s to 1890 s, affirms this assertion.

Before I discuss each of the three main authentication procedures in more detail, I first provide a little more background on how the set of supporting documentation 
was created. I begin by elucidating the coeval meaning attributed to the collection of 'little histories' by craniologists in the mid nineteenth century. I then examine the technologies associated with confirming the credibility of the testimonies contained in such historical accounts and documents. I show that the credibility of the historical accounts was subject to three types of testimonial certification. The first was sociological certification. This implied naming the agent/s involved in the donation, sale or collection of the skull, in order to establish their social and/or professional status. The second was rhetorical validation, as expressed through production of narratives that dramatised the mode of acquisition and the rarity of the materials. The third was anatomical certification, which implied the collation of historiographical information with the trained eye of the craniologist. In this regard, it should be noted that the knowledge contained in the documents attached to the skulls maintains a tense and potentially conflictual relationship with the expert knowledge of the craniologists and physical anthropologists, who claimed to be the ultimate experts in comparative observations of bones in the laboratories. In addition, it must be noted that, because this kind of historiographical knowledge was primarily oriented to affirming the credibility of skulls as 'specimens of human races', exclusions and invisibilities were rife - the absence of indigenous knowledge and cultural sensibilities towards human remains being perhaps its most pervasive occlusions.

\title{
The archives of 'little histories' in nineteenth-century collections
}

\begin{abstract}
Before ... [reading William Lawrence's work on the Natural History of Man], I had felt some curiosity in human skulls which was promoted by various incidents. The lecture given by Mr. Joshua Brookes, in his Anatomical Course, which he illustrated with a series of crania, some of which had a little history attached to them, was always of special interest to me. ${ }^{9}$
\end{abstract}

This is how, in 1867, physician and craniologist Joseph Barnard Davis, a wealthy English landowner, explained what had inspired him to invest some of his fortune in creating a huge collection of 'exotic' human skulls, representing 'the various races of Man [sic]'. At the time, Davis had the largest private collection in the world. ${ }^{10}$

The historical development of craniological expertise has been closely linked to the teaching and professional practice of modern medical anatomy - as denoted by Davis' reference to the fact that he first came into contact with skulls during an anatomy class. Davis' interest in collections of skulls highlights the historical success of comparative or ethnic craniology, which was then considered one of the most important 'branches' of the emerging racial science of 'anthropology'. It should come as

J. B. Davis, Thesaurus Craniorum: Catalogue of the Skulls of the Various Races of Man, in the Collection of Joseph Barnard Davis, London, Printed for subscribers, 1867), v (emphasis added). Trained in medicine, Davis was also landlord in Staffordshire; he acquired the first of his collection of skulls in 1848.

10 The size of Davis' private collection - which at the time of his death included about 1,800 skulls from various parts of the globe - was surpassed only by the public anthropological collections in the Musée d'Histoire Naturelle in Paris. 
no surprise then that Davis' interest was further fuelled by the work of leading doctors who pioneered racial scientific theories in the early nineteenth-century, such as William Lawrence, James Cowles Prichard, Johann Friedrich Blumenbach, and others. However, Davis' reading was preceded by an initial impulse, what he called 'some curiosity' that was triggered by seeing human skulls 'with a little history attached to them' during an anatomy class. In fact, his interest in combining skulls with histories characterised all three decades of his devotion to craniology. Davis was more than a collector of skulls; he was also a collector of histories and of documents.

At the time of his death, in 1881, his collection had been acquired by the Royal College of Surgeons of England, and was valued for the number and rarity of its specimens, as well as for the quality of the associated historical accounts and documentation. At the time, William Henry Flower of the Royal Anthropological Institute noted that, 'nearly all' have 'carefully recorded histories." ${ }^{11}$ An examination of the documents, which are still stored in the College archives, confirms Flower's statement. In four handwritten notebooks, Davis created a Catalogue of Human Crania. ${ }^{12}$ Within the notebooks, he assembled a vast archive of documents - based largely on private correspondence - containing narratives and data on the identity of each skull (gender, age, race, or provenance), and its acquisition process (donation, purchase, exchange, etc.).

Davis' statement, along with the catalogue he created, point to the need to assess the historical significance of practices of preserving small document archives in conjunction with biomaterials in the field of racial anthropology. Davis' collection of documents was certainly not unique to him; as noted, the association of skulls with historical accounts was integral to nineteenth-century anthropological collection methods. Moreover, collections of human bones were integral to the constitution of race as a concept and to the development of the field of craniology. In the late eighteenth century, Blumenbach established the primacy of comparative craniological analysis for the purposes of racial classification, based on the assumption that human skulls offered the most secure basis for building a universal taxonomy of various racial types. The argument was that skulls are more immune to environmental influences and therefore subject to fewer variations over time. As I note below, it was Blumenbach who also proposed the methodological principle of collecting skulls in conjunction with historical documentation. ${ }^{13}$

The 1860s ushered in a period of exponential growth in collections of human remains from European and other countries. Museums with laboratories attached to them began to rapidly acquire and accumulate large quantities of human skulls. ${ }^{14}$

11 W. H. Flower, 'Joseph Barnard Davis', Nature, 26 May 1881, 82-83. Flower chaired the Royal Anthropological Institute of Great Britain and Ireland between 1883 and 1885.

12 J. B. Davis, 'Catalogue of Human Crania', unpublished manuscript, 4 vols. (Archives of the Royal College of Surgeons of England, London, n.d.).

13 See J. F. Blumenbach, The Anthropological Treatises of Johann Friedrich Blumenbach, 1781-1795, T. Bendyshe (trans. and ed.) (London: Longman, 1865).

14 This continued into the early twentieth century. See N. Dias, 'Série de crânes et armées de squelettes: Les collections anthropologiques en France dans la seconde moitié du XIXe siècle', Bulletins et Mémoires de la Société d'Anthropologie de Paris, 1, 3-4, 1989, 205-225; C. Quigley, Skulls and Skeletons. Human Bone Collections and Accumulations (Jefferson, NC: McFarland, 2001). 
The high value attributed to the quantity of skulls in each 'series', to statistics, craniometric instrumentation, and the geographical diversity of specimens, contributed to an explosion of global trafficking in human skulls. Between 1850 and 1930 - the heydays of imperial nationalism, expansionist colonialism, and ideological racism - thousands of human remains from many parts of the planet were transported to many scientific or anthropological museums and laboratories in various parts of the world. This period of concerted interaction between museums, race science, physical anthropology, nationalism and colonialism has been extensively discussed in the literature on the history of anthropology. ${ }^{15}$ However, an important aspect of this concerted interaction is still relatively unexplored in the field of historiography. I am referring here to the value attributed to the historical documentation associated with these anthropological collections.

\section{Collecting skulls, collecting histories}

Davis was not the only collector to value the documentation that formed part of his collection. In general, most museums and skull collectors insisted that an archive of letters, labels, articles, receipts, and other documents be provided, detailing specific information about each of the skulls they obtained, sold, or exchanged. This archive took the form of a 'miniature historiography' - a kind of small-scale, biographical exposition associated with each object. ${ }^{16}$ It was, therefore, not just the skull in its irreducible materiality that mattered to these anthropologists, but also the production of apparently reliable and accurate historical knowledge about the human remains.

The 'histories' were considered a precious component of collections of human remains. Their importance in establishing the objectivity of anthropology - which, it should be emphasised, has been largely overlooked in the historiography of nineteenth century scientific objectivity ${ }^{17}$ - was firmly established. Indeed, this increased as race science was affirmed institutionally in the second half of the nineteenth century. Consequently, museums were not interested solely in skulls. The accepted form of the scientific objectivity of objects - which, as Lorraine Daston remarked, implies 'things devoid of words' ${ }^{18}$ - placed constraints on the use of skulls as racial evidence in the physical anthropological approach of the epoch. That is, the usefulness of human skulls as 'scientific objects' depended on contact being maintained between the materiality of the bones and the historical information contained in the accompanying documents. The validity of a bone as an item of evidence depended - to an large

15 Important examples include B. Douglas and C. Ballard (eds), Foreign Bodies: Oceania and the Science of Race, 1750-1940 (Canberra: ANUE Press, 2008); G. W. Stocking (ed.), Bones, Bodies, Behaviour: Essays on Biological Anthropology (Madison, WI: University of Wisconsin Press, 1988); Zimmerman, Anthropology and Antihumanism.

16 Roque, Headhunting and Colonialism; Roque, 'Stories, Skulls, and Colonial Collections'

17 In particular L. Daston and P. Gallison, 'The Image of Objectivity', Representations, 40, 2001, 81-128; L. Daston and P. Gallison, Objectivity (New York: Zone Books, 2007). These authors assert that the mid nineteenth century was dominated by the principle of 'mechanical objectivity', the definition of which does not, however, include the importance of historiography and documentation of scientific objects. In this sense, the present article can be seen as a means of correcting this absence, thereby helping to restore the importance of 'histories' in the history of scientific objectivity.

18 L. Daston, 'Scientific Objectivity With and Without Words', in P. Becker and W. Clark (eds), Little Tools of Knowledge (Ann Arbor, MI: University of Michigan Press, 2001), 259-284. 
extent, albeit not exclusively - on the quality of its connections to credible words and texts of a historiographical nature. In the vocabulary of the period: the best specimens were those that had 'little histories' associated with them.

The term 'histories' has had an elastic significance in the scientific culture of anthropology. It refers to a complex genre of specific knowledge that evolved in a particular way within the framework of museum practices dating back to the late eighteenth century. The term 'histories' was used to designate the unique set of records associated with each skull or set of skulls. These 'histories' could include biographical data indexing the skull to a specific deceased person - including their name, gender, age, mental or physical state of health at the time of their death, the cause of death, their ethnic group or 'tribe', etc. In addition, the name of the donor, vendor, or collector was usually included, along with the date of acquisition, the place or region where the skull was collected, relevant ethnographic information, and references to other items or texts collected at the same time. Finally, short historical narratives detailing the circumstances in which the specimen had been obtained were also usual. Moreover, researchers also used term 'histories' to refer to documentation and physical archives that came to be associated with the object after it had been collected and traded. This could include letters, invoices, labels, and cabinet numbers.

The importance of this kind of historical record in the mid nineteenth century is evident in catalogues of skull collections produced by several museums around the world. ${ }^{19}$ In theory, anthropological collections were conceived as perfect archives of interconnected histories and things; they implied genuine documental research, archiving, and even storytelling. According to the conservator at England's Royal College of Surgeons, human skulls in anthropological collections required a connection to a network of documents, chronicling 'all the details' known about their past. ${ }^{20}$ A truly scientific skull collection, therefore, comprised not only material objects but also an archive of associated 'histories'. It was desirable (although this did not always happen in practice) that each skull should have a specific archive and history attached to it, and many experts observed this normative standard enthusiastically.

\section{The problem of authenticity and the technologies used to attest to the credibility of histories and collections}

Mere curiosity was not usually the motive collectors identified to explain their interest in attaching short histories to each skull. Above all, their aim was to establish

19 Elise Juzda offers direct evidence of the methodological concern of the American Army Medical Museum's anthropologists and collectors to collect rigorous historical information in conjunction with skulls, while Fenneke Sysling offers similar evidence in the context of Dutch racial anthropology. See E. Juzda, 'Skulls, Science, and the Spoils of War: Craniological Studies at the United States Army Medical Museum, 1868-1900', Studies in History and Philosophy of Biological and Biomedical Sciences, 40, 2009, 161-162; F. Sysling, "Not Everything that Says Java is From Java": Provenance and the Fate of Physical Anthropology Collections', in R. Knoeff and R. Zwijnenberg (eds), The Fate of Anatomical Collections (London: Ashgate, 2015), 195-210.

20 W. H. Flower, Catalogue of the Specimens Illustrating the Osteology and Dentition of Vertebrated Animals, Recent and Extinct, Contained in the Museum of the Royal College of Surgeons of England. Part I. Man: Homo Sapiens, Linn (London: Taylor and Francis 1879), $\mathrm{v}$ (in the annotated copy in the Archives of the Royal College of Surgeons of England, London). Flower contrasted his catalogue, which he described as more 'historic' with what he termed the 'old' and 'descriptive' catalogue kept by his predecessor, Richard Owen. See R. Owen, Descriptive Catalogue of the Osteological Series Contained in the Museum of the Royal College of Surgeons, 2 Vols (London: Taylor and Francis, 1853). 
'authenticity'. Authenticity was crucial if skulls were to be used for the purposes of racial classification in a museum. In particular, determining the genuine 'tribal' and geographical origin of each skull was of major importance. In line with scholarly traditions that emerged after the Enlightenment, geography and ethnology were considered to pertain to a single field of study. Debates about racial classification revolved around questions of the 'geographical distribution of races' as represented on ethnogeographical maps and atlases. ${ }^{21}$ Thus, the historiographical determination of the authenticity of provenance was an essential prerequisite for the 'proper' use of a skull or set of skulls as evidence in racial classification. The preservation of individual historical records was seen as guarantee of the genuine origin and identity of each skull.

Archives thus functioned as a technology for managing the authority of material testimony. This was especially true for collections of so-called modern or contemporary 'exotic' skulls for use in the development of racial typologies. ${ }^{22}$ The risks involved in accepting false specimens (deliberately forged with the intention of adding value and rarity) and of elaborating a false analysis (due to having been misled about the identity of skulls) contributed to the growing importance attached to the historical certification of these objects in the nineteenth and early twentieth centuries. ${ }^{23}$ The 'histories' were seen as a pillar of a system of knowledge based on the specimens' authenticity. Hence, the scientific (and also, ultimately, the economic) value of any specimen was closely linked to its association with a good 'history'. Collectors, donors and other intermediaries involved in transferring human remains from their original places to museums were therefore encouraged to produce and to include this historical information with items that they sent to museums.

\section{Naming donors and gift economies}

Because the authenticity of a skull depended on its set of supporting documents, the authenticity of the documents themselves was managed with great care. In this context, it was not only the presence or absence of histories that concerned scientists but also the level of credibility attributable to these histories. Of course, documents reaching the museums could be false or fairly inaccurate. For this reason, they too were subject to authentication. Because the reliability of the histories was perceived as depending on the social credibility of the donor, seller, and/or collector, one such authentication process involved the naming of donors, as well as the specification of their designation and social status.

21 See C. Blanckaert, 'Géographie et anthropologie: une rencontre nécessaire (XVIIIeme-XIXeme siècle)', Ethnologie Française, 4, 34, 2004, 661-669; B. Douglas, 'Geography, Raciology, and the Naming of Oceania', The Globe, 69, 2011, 1-28.

22 Note however that, since the mid nineteenth century, prehistoric human remains had their 'authenticity' attached not simply to documentation but increasingly also to geological methods. An examination of the historiographical differences in collection practices and attitudes related to collections of prehistoric versus more modern human remains is outside the scope of this paper, but see A. Hurel and N. Coye (eds), Dans lépaisseur du temps: archéologues et géologues inventent la préhistoire (Paris: Muséum national d'histoire naturelle, 2011).

23 For example, the Piltdown skull, presumably discovered on English soil at the beginning of the twentieth century, became world famous. The discovery agitated the scientific community, but the specimen's falsity was denounced a few decades later. See J. S. Weiner, The Piltdown Forgery, 1955 (Oxford: Oxford University Press, 2003). 
Consequently, in institutional catalogues, skull records generally appear alongside donors' names. The donors' social status is conveyed by the inclusion of titles attesting to their nobility, military rank, and other signs of social prestige, such as Sir, Colonel, Dr, etc. The more socially elevated the donor, the less likely that the history attributed to the gift would be discredited. Thus, by associating a skull with the donor's name and social status, museum officials were adding a credential of authenticity to the object. Moreover, when a skull was a gift or a present, the very gesture of making a donation constituted a moral guarantee of the veracity of the specimen. In catalogues, mention is therefore often made of skulls acquired by the museum as gifts from generous and 'disinterested donors', 'respectable friends' or 'honourable persons. ${ }^{24}$

The importance of naming the donor is understandable in the light of the gift economy that seems to have dominated the movement of human skulls into scientific institutions. While some skulls were acquired via monetary transactions, and purchased from an intermediary (usually a European) in exchange for a sum of money, a larger number seem to have been donated as gifts. Since the early eighteenth century, networks of donors had been key to the formation of European museum collections linked to natural history and anthropology. ${ }^{25}$ Some of these networks were informal in nature, and based on elective affinities, class and social status, or strong, emotional, and personal relationships. Others took on more formal and bureaucratic dimensions when the obligation to collect was institutionalised within, for example, the framework of colonial administrations. Either way, museums became centre points in circuits of exchange between the colonies and Northern metropols in a version of what Marcel Mauss called 'gift economies. ${ }^{26}$ Simply put, museums took part in systems of exchange and circulation through a process of gift and counter-gift. In theory these transactions were voluntary and disinterested but, in fact, they were governed by normative obligations. For collectors, a donation of skulls presupposed various rewards in return: objects, words or gestures that were means of generating further economic, symbolic, or social capital. These could take the form of, for example, improved status or the cultivation of friendship networks. In addition, donors could receive a credit for personal favours from the museum curator, director or technicians, which could be used to obtain social, material or symbolic advantages in future circumstances.

A striking aspect of this gift economy was the supposed altruism through which it took place. Based on a patriotic and/or scientific and moral language, 'gifts' were sent to institutions in the name of the greater collective and abstract good - 'the progress of science' or 'the good of the country'. However, the altruistic morality of

5 Amiria Henare, for example, showed how practices of donation of Maori artefacts to museums were important 'to cultivate friendships and relations of patronage' in the eighteenth century. A. Henare, Museums, Anthropology and Imperial Exchange (Cambridge: Cambridge University Press, 2005), 71. See also K. Pomian, Collectors and Curiosities: Paris and Venice, 1500-1800 (Cambridge: Polity Press, 1990), 42-43: A. Secord, 'Corresponding Interests: Artisans and Gentlemen in Nineteenth-Century Natural History', British Journal for the History of Science, 27, 1994, 383-408. 
making a gift to a museum was clearly also compatible with satisfying more prosaic individual interests. In the case of human remains, material and/or symbolic counter-gifts were implicit in their offers and acceptances. For example, museum authorities might offer words of deference and praise to a donor; sometimes they could even recommend that a donor be awarded a medal, diploma, praise or other official distinction. ${ }^{27}$ Indeed, in the context of this peculiar 'gift economy', the mere naming of the donor in the historical documentation associated with a skull could serve as a counter-gift, acting as a gesture of recognition and gratitude for a disinterested' donation. Implicit or explicit compliments paid to donors are a regular feature of catalogues, registration cards, labels, institutional reports and even scientific articles. See, for example, J. L. Dusseau's comment in the preface to a 1865 catalogue of skulls held by Amsterdam's Museum Vrolik. Recognising the importance of keeping a record of the names of the donors, as well as their respective social designations, Dusseau wrote:

In fair return, and driven by a natural sentiment of gratitude, Mr Vrolik made sure to ostensibly link the donor's name to every donated object, which has the advantage of constituting a set of documents that is very useful for the history of the collection. ${ }^{28}$

\section{The literary record: the case of heroic narratives}

While the practice of naming donors was overseen by the museum professionals, the very stories contained in the accompanying documents involved narrative and rhetorical processes that served to persuade the anthropologists and museums receiving the gifts of the objects' value. That is, the rhetoric used in the short histories about how the objects were collected helped add what might be called a 'currency of authenticity' to the skulls. This literary work was usually undertaken by the person offering a specimen to a museum. Indeed, human skulls could gain a singular rarity and value in the light of the narratives that were provided about the ways in which skulls were acquired in the field. For this reason, colonial collectors, donors or intermediaries provided this information with the object when they could. In contemporary archives of the collections, however, the existence of such narratives is less common than other forms of historical data and indexable categories, such as the geographical origin, date, sex, or age of the person whose skull had been donated, and the donor's name. When accounts of the circumstances of the acquisition, or the life history of the man or woman to whom the skull belonged were added, the perceived veracity of the materials increased.

Of course, these narratives assumed very different modalities and commonly disregarded indigenous cultural assumptions and meanings. However, in terms of

27 See Zimmerman, Anthropology and Antihumanism, 168-169.

28 J. L. Dusseau, Musée Vrolik. Catalogue de la collection d’anatomie humaine, comparée et pathologique de M. M. Ger. et W. Vrolik (Amsterdam: Roever Kröber, 1865), vii (my translation). The museum is named after Dutch anatomist and pathologist Willem Vrolik, whose extensive anatomical collection is held there. 
authenticity, the most effective stories were those that offered readers a brief account of the collection process, using the moral form and dramatic atmosphere of a heroic narrative. In this powerful narrative form, the narrator or central character (usually a male collector in the field) was presented as the hero of a skull-collecting adventure. Overcoming multiple difficulties and obstacles, including local superstitions and the resistance of local populations, the collector or donor added value and authenticity to the skulls by emphasising their qualities as rare objects obtained at the expense of great physical effort, and even loss of life. Likewise, narratives reinforcing the uniqueness of such objects were emphasised. Implying that skulls represented individuals of a particular social notoriety (such as 'chiefs', 'rebels' or 'infamous bandits'), or were from 'tribes' 'at risk of extinction' due to their contact with European settlers, invariably enhanced their value.

Catalogues and archives of anthropological collections assembled in the second half of the nineteenth century contain several examples of such narrative constructions. For example, Museums Victoria in Melbourne holds a 'Papua' skull purchased in 1901, said to derive from a 'notable tribe'. The collector sold it to the museum with a narrative describing how the skull was 'saved' by the collector after a native woman had 'hidden' it 'inside her dress' to prevent the authorities from destroying it. ${ }^{29}$ In other cases, the 'life story' of the deceased 'owner' of a skull occupies the centre of collectors' or anthropologists' interests. For example, in 1897, Henry Balfour, of Oxford's Pitt Rivers Museum, reported on a skull that was used as a drinking vessel, and noted that his 'interest' lay in the 'personal history' of the skull's 'former owner. ${ }^{30}$ In another case, British museum curator and comparative anatomist William H. Flower recorded and preserved just such a narrative, the aesthetic and rhetorical elements of which demonstrate this type of heroic account of collection in an exemplary way while, at the same time, inadvertently testifying to the violence of grave-robbing. Flower described a 'Tasmanian' skull, obtained from 'a grave on the island of Bruni', whose unique value derived from its supposed rarity: according to Flower, it represented the skull of the 'last Tasmanian. ${ }^{31}$ This level of 'rarity' was high and was proven by the dramatic narrative associated with it by the skull's collector, Dr Archibald Sibbald, in Tasmania, in 1854. With evident pleasure, Flower recorded this story in his catalogue, as follows:

The circumstances under which this specimen was obtained are described in the following note from the donor: - 'When H.M.S. 'Fly' was at Hobart Town in 1842, a young gentleman of great intelligence and adventure volunteered to accompany Mr M'Gillivray and myself to the place of interment of

This narrative and its contexts are analysed in detail in Roque 2011. On the dangers involved skull collecting, see R. Roque, 'Human Skulls, Dangerous Wanderers', in L. Arndt, C. Lozano and M. Abonnenc (eds), Crawling Doubles: Colonial Collecting and Affect (Paris: Editions B42, 2016), 253-273.

30 H. Balfour, 'Life History of an Aghori Fakir: With Exhibition of the Human Skull Used by Him as a Drinking Vessel, and Notes on the Similar Use of Skulls by Other Races', Journal of the Anthropological Institute of Great Britain and Ireland, 26, 1897, 340-357.

31 Flower, Catalogue of the Specimens, 206. In the 1870s, it was believed that the natives of Tasmania were, like the Australian Aborigines, doomed to brutal extinction as a result of European colonisation of their island. See R. McGregor, Imagined Destinies: Aboriginal Australians and the Doomed Race Theory, 1880-1939 (Melbourne: Melbourne University Press, 1997). 
the last of the aboriginal inhabitants of Tasmania who had died in their own land. I will not speak of our labours and dangers in the adventure: it was the painful occasion of the loss of two out of our three boats, with their crews of nine men ... Tired, but determined, we dug about six feet down, and to our disappointment found ashes of a burning. We dug into another grave, and found it had been disturbed. On opening a third we were more fortunate; a layer of Eucalyptus-bark stopped the spade, and on being opened disclosed the body of a young female in a perfect state of preservation. The water began to flow into the grave; but we soon obtained and carried off the head, which accompanies this note. ${ }^{32}$

In each case, the literary account of the life of the person, or the acquisition of the skull, added extra value, with uniqueness or rarity making the object worth more than its own materiality.

\section{Documentary authenticity and the filter of the craniological perspective}

In some situations, these sociological and rhetorical procedures proved insufficient to guarantee confidence in the authenticity of specimens. Even when accompanied by seemingly credible histories, skulls had to withstand the critique of craniological expertise - the painstaking anatomical scrutiny of the 'specialist gaze', honed over many hours of laboratory work. ${ }^{33}$ While anthropologists evaluated the objectivity of the historiography of the skull, and decided on the identity and degree of authority to be attributed to the object, the possibility that a skull could have been wrongly labelled, or given false or inaccurate historical information, had to be considered. In short, the histories required anatomical validation, and had to pass the final test of laboratory authentication.

Certification of the skull by specialists in comparative craniology assumed special importance (and complexity) when it came to validating the ethnic or racial identity of each skull, regardless of whether or not this had been documented. As a methodical precaution, craniologists reserved their right to have the final say on the race to which specimens belonged. The sensitive nature of the racial identification of skulls was described by the celebrated American ethnologist and collector, Samuel G. Morton, who made the following remark in the introduction to his 1849 catalogue:

In every instance where a doubt is entertained as to the tribe or nation to which the skull belonged, it is expressed by a mark of interrogation; and where no clue exists for such information, the deficiency is noted accordingly. I have sometimes had the skulls of both Europeans and Africans sent me by mistake for those of Indians; that these should occasionally be 
mingled in the same cemeteries is readily understood; but a practised eye can separate them without difficulty. ${ }^{34}$

Few donors or collectors in the field had specialised anatomical training. In such cases, physical anthropologists, with their 'trained eyes', took on the task of working out histories and identities for the bones, based on their investigations at a laboratory table. Anatomical observation was considered the final word on the geographic origin and ethno-racial nature of a bone and these racial anatomists claimed ultimate authority in conferring ethnic, and even historical, identities on the human remains they examined. Their authority was understood as superior to that of donors, intermediaries, vendors, or collectors and the work they did to gather, write and provide historical documentation. Methods of examining skulls in a laboratory were thus proclaimed as an autonomous technology for managing the identities, and even the histories, of human skulls.

For this reason, the relationship between a craniologist's knowledge and the documentation associated with particular skulls was potentially tense and, in certain cases, proved directly contradictory, especially in relation to the race, ethnicity and geographical origin of a skull. Where documentary information was non-existent, craniologists could invoke their experience of anatomical analysis to give a skull its missing ethnic identity. Where documentation was present, anatomical experts could confirm its veracity but might also deny the identities proposed by labels and archives.

In many cases, they confirmed the history, and authenticity of material. For example, in relation to a skull attributed by its donor to a 40 -year-old man, from Brazil, Davis stated that he had verified the authenticity of this information after having directly observed other skulls of the same geographical origin in the collections of the Swedish collector, Anders Retzius. 'Examination of these,' he concluded, 'shows that they are very similar to mine ... I'm convinced of the genuineness of this very rare and valuable skull. ${ }^{35}$ However, a craniologist's trained eye could also correct, or even make up for, the absence of historical information by retro-projecting a past and racial identity onto a skull.

In Flower's 1879 catalogue for the Royal College of Surgeons, in relation to a skull originally acquired and listed under the category 'Bushman', a handwritten note (added by a museum curator at an uncertain date, but perhaps after 1907) notes 'Skull, the history of which is not known but which presents typically Bushman features that it is assigned with little hesitation to this race. + . Presented by General Lasseter 1919.36 The same catalogue carries a series of similar annotations, correcting, doubting or certifying the authenticity of certain items. In relation to Skull No. 1113a, is

34 S. G. Morton, 'Catalogue of Skulls of Man and the Inferior Animals, in the Collection of Samuel George Morton', in J. A. Meigs, Catalogue of Human Crania in the Collection of the Academy of Natural Sciences of Philadelphia, 1849 (Philadelphia, PA: Merrihew \& Thompson, 1857), 13-14. For several years, Morton owned the largest private collection of skulls representing the 'different races of man [sic]'. In the 1860s, the size of his collection was overtaken by that of Joseph Bernard Davis in the United Kingdom.

35 Davis, Catalogue of Human Crania, Vol 1.

36 Anonymous, c. 1907, in Flower, Catalogue of the Specimens (annotated archival copy). 
the note: 'A cranium from the South Pacific, the exact locality of which is unknown, but with characters resembling those of the Tasmanian race. ${ }^{37}$ Or, about No. 1110: 'A skull from a Tasmanian (female). From Dr Bedford. Presented by Sir Joseph D. Hooker, 1866. A conservator later added the following handwritten commentary to the record, resulting, it seems, from subsequent reinspection of the specimen: 'very doubtful of Tasmanian. ${ }^{38}$

These gestures, sometimes of falsification, sometimes of verification, sometimes of substitution, are often found at the micro level in these archives - in catalogue entries, on small individual cards, in letters, and on labels. However, in certain circumstances, the tensions generated by the encounters between the collectors' histories and the craniological gaze could go beyond the laboratory, and erupt in the public sphere, in the form of scientific controversies - about racial classification, for example - thereby underlining the problem of history and the authenticity of collections.

In this respect, a controversy that unfolded in Portugal about the authenticity of a collection of skulls from Timor, acquired in 1882 by the museum of the University of Coimbra, is paradigmatic. ${ }^{39}$ No documents or histories accompanied the collection and without these, the authenticity of the collection was uncertain. In 1894, Coimbra craniologist Barros e Cunha used this collection to propose a classification of the Timorese as part of the 'Papuan race'. A few decades later, in 1934, this racial classification was discredited by rival anthropologists in Portugal because the skulls lacked the documentary and historiographical data that could prove their authenticity. Thus, in cases of dissonance between the historical record and craniology, evidence provided by the former can be invaluable. Although craniologists claimed that laboratory examinations should provide the last word on ethno-racial categorisation, their dependence on historical documentation could lead to a questioning of craniology's authority. Ultimately, the latter could be discredited by the authority of a short historiography.

\section{Conclusion}

In this article, I have suggested that in anthropology's economy of trust, the acknowledged authenticity of skulls depended intimately upon the authority of associated histories and documents. As a result, the constitution of skulls as 'authorised objects' in the field of physical anthropology can only be understood in relation to the constitution of what I call 'authorised histories.' Trust in the testimonial value of the skulls depended upon trust in the testimonial value of the histories, the credibility of which depended, in turn, on specific certification criteria. For example, where donors had sufficient social or professional status, this could help guarantee the authenticity and scientific standing of material they collected. In addition, anthropologists subjected the historiographic knowledge associated with the objects

37 Flower, Catalogue of the Specimens, (annotated archival copy).

38 Anonymous, in Flower, Catalogue of the Specimens, (annotated archival copy).

39 For an in-depth analysis of this controversy see Roque, Headhunting and Colonialism, Ch. 6. 
to another kind of certification, based on the authority of a craniologist's anatomical expertise. Finally, the very narrative and rhetorical dimension of the stories could add particular value to certain skulls.

Missing histories therefore constituted a serious problem in the economies of credibility affecting skulls as scientific evidence in the race science of the past. It follows from this that the very concept of 'race', both in theory and taxonomy, was inextricably linked to the inscriptions and knowledge forms that were part of archival and documentary texts linked to collections of human skulls. This assertion challenges historians and other scholars of race to reconsider the notion that racial thought was concerned purely with the strictly biological or anatomical aspects of such collections. To assign a 'race type' or a racial history to human remains was a practice that was never reduced to anatomy alone - it involved an engagement with archival and historiographical work.

In other words, raciology has not existed in isolation from historiography. In nineteenth-century Europe, 'races' could hardly be reliably verified without 'object histories. For researchers bent on using human skulls as evidence of different races, missing historical information was a key problem that emerged in the spaces between collecting and archiving - between objects and documents, and between bones and their histories. Missing information at the intersection of attachments that bind (or should do) human remains to credible sets of associated texts - from scientific articles or monographs to museum catalogues, archive registers, paper labels or ink tattoos applied to the bones themselves - meant that skulls became untrustworthy in testifying to human difference. For this reason, human skulls considered to be 'unprovenanced' or 'undocumented' - that is, skulls with missing historical and biographical records - were, and perhaps still are, a problem in the field of craniological science, while biographical information ensured their value and credibility as collectable items.

Miniature forms of historicising human remains in museums also produced and governed the ways in which skulls were classified as halfway between 'human subjects' and 'material objects'. For example, in the context of phrenology, criminology, medicine, and the study of genius personalities, skulls can be associated with specific people and their personal biographies. ${ }^{40}$ However, since the 1860 s, the raciological paradigm contributed to the disappearance of people's names as subjects from many histories of human skulls. Instead of individuals' names, the names of races, ethnic groups, and geographical sites were included in skull inscriptions. In this sense, in colonial collections of human remains, missing data about the personal names and lives of the deceased can be seen to result partly from the historical configuration of the scientific disciplines involved.

I have shown that, in the past, historiographical technologies have had a major impact on the credibility and subsequent use of skulls as scientific evidence. The

40 A remarkable example of a medical collection with individualised stories is Joseph Hyrtl's skull collection housed at the Mütter Museum in Philadelphia since 1874; see M. Marshall, 'Objects of Intrigue: Every Skull has a Story', Atlas Obscura, 4 November 2014, https://www.atlasobscura.com/articles/objects-of-intrigue-every-skull-has-a-story (accessed February 2018). 
value of a skull in race science depended on the existence or absence of a little history' that had the potential to aid in accrediting or discrediting the item. Today, despite the general discrediting of racial craniology over the course of the twentieth century, the association between bones and histories continues to be important in scientific practice. That is, contemporary museum curators and anthropologists still attach considerable significance to the accumulated archives and 'histories' of the human remains in their collections. Here too, short histories remain important to scholarly disciplines dedicated to studying human skeletons, as well as to political debates about the ownership of human remains, and especially when it comes to decisions about the eventual repatriation of the remains of indigenous peoples to the communities from which they were removed.

Accordingly, in the 1990s, members of Australia's National Skeletal Provenancing Project developed extensive archival research with a view to locating 'the original provenance of the many Aboriginal and Torres Strait Islander Ancestral Remains held in Australian museums. ${ }^{41}$ As Australian researcher Deanne Hanchant put it, 'determining original provenance is crucial in facilitating the return of remains to communities.' ${ }^{42}$ Similarly, in the 2000s, in Britain, the Working Group for Human Remains in Museums Collections recommended an investigation into 'the history of a particular acquisition, from the time of removal onwards' as a critical step in 'judging the merits of its current possession. ${ }^{43}$ In the 2010s, extensive colonial collections of African skulls in Berlin were the object of comparable historical research, as German authorities began to reassess the injustice of their ownership and consider their repatriation. Indigenous communities and formerly colonised countries also see historical data as critical to repatriation claims. In 2016, for example, Igor Cesar, Rwandan ambassador to Germany asserted that before his government decided on whether or not to make demands for restitution, the histories of the skulls had to be known: 'Our interest at the moment is to know the history behind these skulls. And when we know exactly what that is, we will think about how best to deal with it. ${ }^{34}$ Without archival information on the provenance of ancestral human remains, it is difficult to ascertain the legality of their ownership and for restitution demands to take effect. In sum, without establishing a 'history' about their past, it is difficult to decide on their future.

It is therefore time to rewrite histories for these collections, to give them a present and a future beyond the tropes of the colonial and racialised 'little histories' usually

41 D. Hanchant, 'Practicalities in the Return of Remains: The Importance of Provenance and the Question of Unprovenanced Remains', in C. Fforde, J. Hubert and P. Turnbull (eds), The Dead and their Possessions: Repatriation in Principle, Policy and Practice, 312-316. (London: Routledge, 2001), 312.

42 Hanchant, 'Practicalities in the Return of Remains'

43 Working Group on Human Remains in Museum Collections, Report of the Working Group on Human Remains in Museum Collections, 14 November 2003, 147, https://plone.unige.ch/art-adr/cases-affaires/17-tasmanian-human-remains-2013tasmanian-aboriginal-centre-and-natural-history-museum-london/working-group-on-human-remains-report-14november-2003 (accessed 25 September 2018).

44 Igor Cesar cited in 'Germany to Investigate 1,000 Skulls Taken from African Colonies for "Racial Research", The Guardian, 6 October 2017, https:/www.theguardian.com/world/2017/oct/06/germany-to-investigate-1000-skulls-taken-from-africancolonies-for-racial-research (accessed 25 September 2018). 
associated with them. I hope this article contributes to raising awareness of the historiographical epistemes entailed in collections gathered for racial research as part of the ultimately failed efforts of craniologists to make 'race' a credible scientific reality. We must begin by acknowledging that the archival texts associated with such skulls are themselves embedded in the epistemological structures of raciology. Postracial and antiracist archival and historiographical work needs to critically assess colonial and racial historiography in terms of what existing or missing 'histories' enable and what they obstruct or exclude. 